\title{
胆石症に随伴する脞障害の実態と臨床像
}

\author{
久留米大学医学部第 2 外科 (主任 : 古賀道弘教授) \\ 小林重矩
}

\section{THE CLINICAL STUDY OF PANCREATIC DISORDERS ACCOMPANIED WITH CHOLELITHIASIS}

\section{Shigenori KOBAYASHI}

The 2nd Department of Surgery, Kurume University School of Medicine

胆石症72例を対象に, PS 試験による膆外分泌機能, 開腹時膵触診による硬化度, 生検膵の組織学的検 索を行い，随伴する脺障害の実態を解明し，から臨床検査所見よりその臨床像を検討した．その結果，外 分泌機能障害 27 例 $37.5 \%$ ，硬化病変 34 例 $47.2 \%$ ，組織学的膆病変 16 例 $22.2 \%$ (うち慢性膵炎 4 例 $5.6 \%$ ) の随伴がみられた。随伴性愺障害の臨休像は特に胆道造影叔よび低緊張性十二指腸造影に批ける異常所見 を示す症例に膵障害合併頻度が高く，形態学的検査にてその存在可能性が推測された。

索引用語 : 胆石症随伴性膵障害, 膵外分泌機能障害, 膵硬化病变, 組織学的膵病变, 膵障害の臨床像

\section{はじめに}

胆道亡揱は発生・解剖, 病態生理など種々な面で密接 な関連を有し，臨床面に抮いても注目していればこれ ら両者の相関の事実に遭遇するものである.1901年, opie $^{1)}$ は vater 乳頭部汇結石が莰頓した急性壊死性膵 炎死亡例の 剖検から，その発生機序汇関し, common channel theory を提晿し, 以来, 多くの研究発表がさ れ，胆石症と膵炎の関連は諸家の意見の一致するところ となった．たしかに脺资に胆石症が高率に合併するのは 事実ではあるが，逆に，胆石症に膵炎が合併する頻度は 胆石症の数からみれば非常に低率で，その相関が疑われ るほどである。しかし，胆石症には軽症脺炎とも推測さ れる随伴性脺障害がかなり高率に合併し，これら膵障害 は軽症ゆえに基礎疾患の胆石症の中に隠れ, 相当高度に 障害が進行しない限り，臨床面では容易に見逃され，胆 石症に対する治療により軽減あるいは治癒していくので ある.しかし, これら萃障害も軽症とはいえ, その経過 いかんでは急性あるいは慢性膵炎に進展する可能性をひ め，ひいては胆石症手術予後に関与する一因にもなり， 胆石症に随伴寸る膵障害のむつ臨床的意義はきわめて興 味深いものがある.そこで著者は自験例をるとに，これ ら胆石症に随伴する膵障害の実態と 臨床像の検索を行

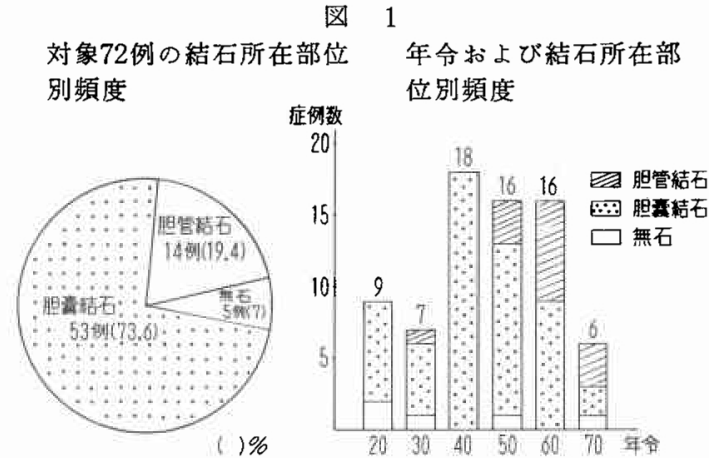

い，その臨床的意義について考察した． 対象および研究方法

A. 対象症例 (図 1 )

昭和 47 年以降約 3 年間に当教室において手術を施行し た無石胆襄炎を含さ胆石症例で，術前の PancreozyminSecretin 試験，開腹時の脺硬化度判定，および薪生検が とすに施行しえた72例を対象にした。症例の性別内訳は 男子27例, 女子 45 例で, 年踹分布は21歳より77歳である. 症例の結石所在部位別内訳は無石胆囊炎 5 例, 胆翼結石 53 例，胆震胆管結石 8 例，胆管結石 6 例（内，肝内結石 
3 例)である.

B. 研究方法

症例は肝内結石も含め，胆管に結石があれば一括して 胆管結石症とし, 無石群 ( 5 例), 胆囊結石群 (53例), 胆 管結群（14例）の3 群に大別し検索した。

1. Pancreozymin-Secretin 試験（以下，PS 試験と略 称）による膵外分泌機能障芒の検索.

PS 試験は日本脺臓病臓病研究会 PS 試験委員試案の 方法に準じ施行した。午の評価判定は液量 $1.6 \mathrm{ml} / \mathrm{kg}$

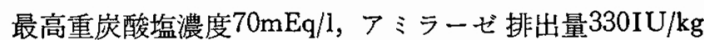
(Blue-Starch 法) を 3 因子の正常下限值とし，3因子と も正常範囲内にあれば正常，1 因子以上の低下があれば 外分泌障害とし，1 因子低下は軽度障害，2因子低下は 中等度障害，3因子低下は高度障害とし検索を行った。

2. 膵硬化病変の検索

開腹時，膵触診による硬化度判定は正常軟と硬化病変 に分け，さらに硬化病変は軽度硬之高度硬に分類し検討 した。

3. 術中採取膵組織切片の組織学的検索

膵の組織切片は充分に膆実質を確かめ採取し，ホルマ リン固定後，Hematoxirin-Eosin 染色を行い検索した。

因 2 膵組織所見

僈性膵炎以外の組織学的变化
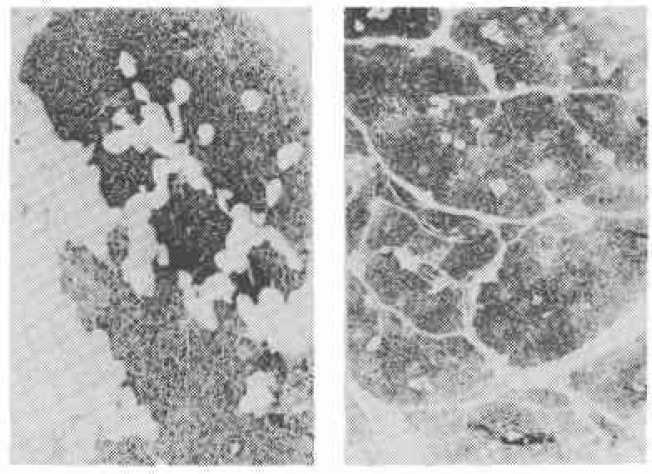

軽度慢性膵炎

中等度慢性膵炎

高度慢性膵炎
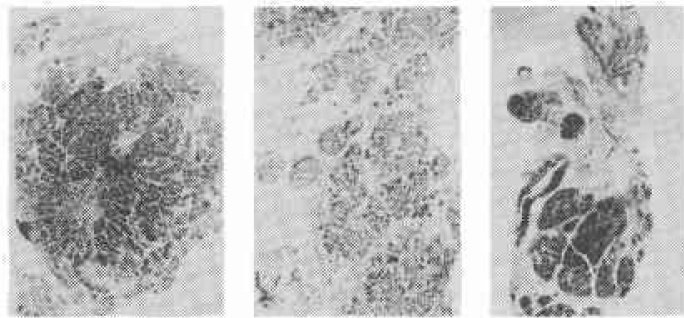

組織学的に 異常所見を認めるものを 組織学的病変例 と し，慢性萃炎とそれ以外の組織学的変化群に分けた。組 織学的慢性膵炎の判定は日本膵臓病研究会の診断基準に 基づき軽度，中等度，高度に分類した．僈性膵炎以外の 組織学的変化所見とはとくに炎症性変化を特有として明 らかな異常所見を認めるもので，慢性膵炎程の小葉間の 線維化が著明ではなく，血管および膵管周团の線維化， 腺細胞萎縮, 細胞間離開, 脂肪变性, 細胞浸潤等の所見 が明らか認められるものとした（図2）.

4. 臨床検査成績の検索

随伴性膵障害の臨床像を検討するため，下記項目の検 索を行った。

i ) 病悩期間との関連

ii ) 背部疼痛との関連

iii）血液生化学検査成績との関連

iv) 形態学的臨床像との関連

a . 胆道造影

b . 低緊張性十二指腸造影

臨床検査の方法, 評価判定の細目は成績の項で一括す る。

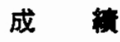

I ．胆石症に随伴する脺障害の頻度 対象72例中

$\begin{array}{llr}\text { 脺外分泌機能障害 } & 27 \text { 例 } & 37.5 \% \\ \text { 膵硬化病変 } & 34 \text { 例 } & 47.2 \% \\ \text { 組織学的膵病変 } & \text { 16例 } & 22.2 \% \\ \text { 組織学的慢性膵炎 } & 4 \text { 例 } & 5.6 \%\end{array}$
であった（表 1 ).

表 1 随伴性腪障害の頻度

\begin{tabular}{|c|c|c|c|c|}
\hline & $\begin{array}{c}\text { 無石群 } \\
5 \text { 例 }\end{array}$ & $\begin{array}{l}\text { 胆霍 } \\
\text { 結石 } \\
53 \text { 例 }\end{array}$ & $\begin{array}{c}\text { 胆 管 } \\
\text { 結石群 } \\
14 \text { 例 }\end{array}$ & $\begin{array}{c}\text { 計 } \\
72 \text { 例 }\end{array}$ \\
\hline $\begin{array}{l}\text { PS 試験による } \\
\text { 腪外分泌機能障害 }\end{array}$ & $\begin{array}{l}3 \\
(60)\end{array}$ & $\begin{array}{c}17 \\
(32.1)\end{array}$ & $\begin{array}{r}7 \\
(50)\end{array}$ & $\begin{array}{c}27 \\
(37.5)\end{array}$ \\
\hline $\begin{array}{l}\text { 硬化度よりみた } \\
\text { 腪硬化病変 }\end{array}$ & $\begin{array}{c}\mathbf{5} \\
(100)\end{array}$ & $\begin{array}{c}19 \\
(35.8)\end{array}$ & $\begin{array}{c}10 \\
(71.4)\end{array}$ & $\begin{array}{c}34 \\
(47.2)\end{array}$ \\
\hline 組織学的苹病変 & $\begin{array}{l}1 \\
(20)\end{array}$ & $\begin{array}{c}9 \\
(17.0)\end{array}$ & $\begin{array}{c}6 \\
(42.9) \\
\end{array}$ & $\begin{array}{c}16 \\
(22.2)\end{array}$ \\
\hline 組織学的僈性椫炎 & $\begin{array}{l}0 \\
(0)\end{array}$ & $\begin{array}{c}2 \\
(3.8)\end{array}$ & $\begin{array}{c}2 \\
(14.3)\end{array}$ & $\begin{array}{c}4 \\
(5.6)\end{array}$ \\
\hline
\end{tabular}

1）膵外分泌機能障害の頻度（表 2 ）

PS 試験による外分泌障害は72例中27例 $37.5 \%$ で，軽 度障害 19 例 $26.4 \%$ ，中等度障害 6 例 $8.3 \%$, 高度障害 2 例 $2.8 \%$ とその多くは軽度障害であった。結石所在部位 
表 2 勝外分泌機能障害の頻度と障害因子

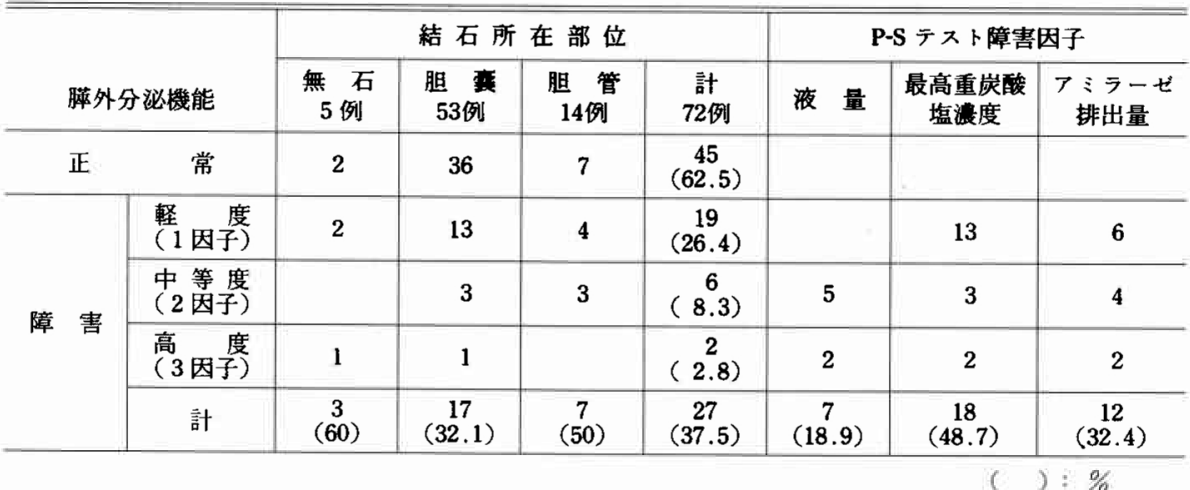

別々は無石例 で60\%，胆㐮結石 $32.1 \%$ ，胆管結石50\% で，頻度としては無石例は症例が少い為断定できない が，有石例では胆襄結石に比へ胆管結石群に高率であっ た。なお，PS 試験障害因子総数 37 中，液量障害は 7 因 子 $(18.9 \%)$,アミラーゼ排出障害12因子 $(32.4 \%)$,で, 最高重炭酸塩濃度障害が 18 因子 $(48.7 \%)$ と約半数を占 め, 最も多かつた。

2）膵硬化病変の頻度（表 3)

表 3 荤硬化病度の頻度

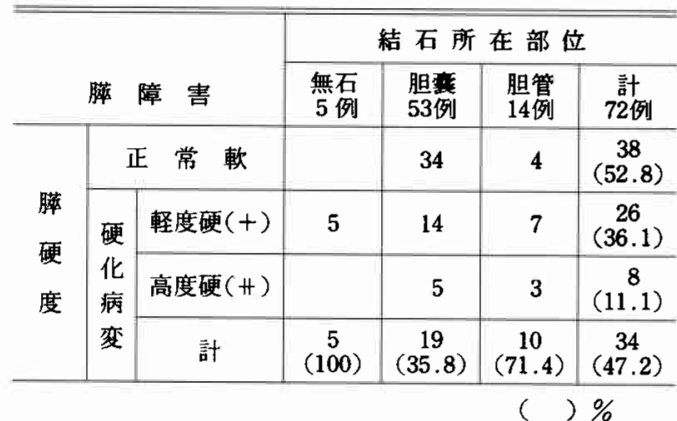

術中膵触診による硬化病変は72例中 34 例 $47.2 \%$ で, 軽 度硬 26 例 $36.1 \%$, 高度硬 8 例 $11.1 \%$ であった。結石所在 部位別々は無石例で全例100\%に，有石例では胆䧶結石 で35.8\%，胆管結石で $71.4 \%$ と胆管結石群に高率にみら れた.な撫石例は全例軽度の硬化病変であった。

3）組織学的膵病変叔よび慢性膵炎の頻度（表 4)

術中採取膵組織切片の検鏡にて組織学的膵病変を認め

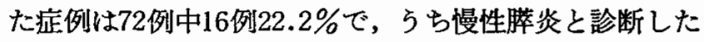
症例は 4 例 $5.6 \%$, 慢性膵炎以外の組織学的变化群 が 12 例16.6\%であった. 結石所在部位別の組織学的膵病変の
表 4 病理組織所見と組織学的慢性苹炎の頻度

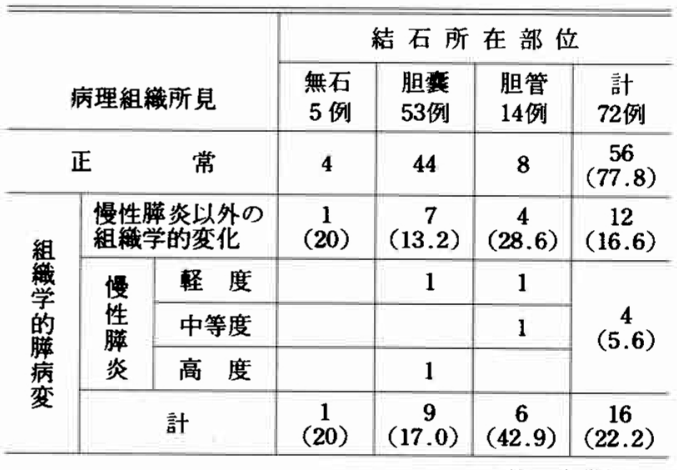

表 5 䐙外分泌機能と腷硬度との関連

\begin{tabular}{|c|c|c|c|c|c|c|}
\hline \multirow{2}{*}{\multicolumn{2}{|c|}{ 䐙外分淡 }} & \multirow[b]{2}{*}{$\begin{array}{l}\text { 正常 } \\
\text { 45例 }\end{array}$} & \multicolumn{4}{|c|}{ 櫒外分泌障害 } \\
\hline & & & $\begin{array}{l}\text { 軴度 } \\
19 \text { 例 }\end{array}$ & $\begin{array}{c}\text { 中等度 } \\
6 \text { 例 }\end{array}$ & $\begin{array}{l}\text { 高度 } \\
2 \text { 例 }\end{array}$ & $\begin{array}{c}\text { 計 } \\
\text { 27例 }\end{array}$ \\
\hline \multicolumn{2}{|c|}{$\begin{array}{c}\text { 正 常 軟 } \\
\text { 38例 }\end{array}$} & 31 & 5 & 2 & 0 & $\begin{array}{c}7 \\
(18.7)\end{array}$ \\
\hline \multirow{3}{*}{$\begin{array}{l}\text { 萍 } \\
\text { 硬 } \\
\text { 化 } \\
\text { 病 } \\
\text { 変 }\end{array}$} & $\begin{array}{r}\text { 軽度硬 } \\
26 \text { 例 }\end{array}$ & 11 & 12 & 2 & 1 & $\begin{array}{c}15 \\
(57.7)\end{array}$ \\
\hline & $\begin{array}{r}\text { 高度硬 } \\
8 \text { 列 }\end{array}$ & 3 & 2 & 2 & 1 & $\begin{array}{c}5 \\
(62.5)\end{array}$ \\
\hline & $\begin{array}{l}\text { 計 } \\
\text { 34例 }\end{array}$ & $\begin{array}{c}14 \\
(31.1)\end{array}$ & $\begin{array}{c}14 \\
(73.7)\end{array}$ & $\begin{array}{c}4 \\
(66.7)\end{array}$ & $\begin{array}{c}2 \\
(100)\end{array}$ & $\begin{array}{c}20 \\
(74.1)\end{array}$ \\
\hline
\end{tabular}

頻度は無石例では20\%，有石例では胆倳結石で $17.9 \%$, 胆管結石で $42.9 \%$ と胆管結石群に多くみられた。なお， 慢性膵资の 4 例は胆豪結石，胆管結石に各 2 例ずつであ った。 
II . 膵外分泌分泌機能障害 と膵硬化病変の 関連（表 5)

対象72例中，外分泌障害および硬化病変をともに合併 した症例は20例 $28.7 \%$ で，これは外分泌障害27例中の $74.1 \%$, 硬化病変34例中の $58.8 \%$ にあたる. 両者の関連 は表 5 に示すごとく，外分泌障害の頻度は膆硬度が正常 軟では18.4\%に対し，硬化病変では $58.8 \%$, 逆に硬化病 変の頻度は外分泌正常例で31.1\%に対し，障害例で74.1 \% と頻度が増し，両者間には相関傾向が認められた．外 分泌障害例にはかなり高率の硬化病変が認められる事よ り外分泌障害があれば硬化病变が存在する可能性を推測 しうるが，逆に硬化病変に合併する外分泌障害の頻度は あまり高率とはい方ず，外分泌正常例でも $31.1 \%$ 亿硬化 病変の合併がみられ，高度の硬化病変 8 例比も3 例は外 分泌障害が認められないなど，硬化病変はかならずしも 外分泌障害の存在を推測しえる指標にはなりえず，両者 間には相関傾向はみられても明らかな相関とはいいがた
い，すなわち，機能障害はある程度膵の硬化を推測しえ るが，逆に膵の硬化より機能障害を推測することは困難 といわざるをえない。

III. 組織的膵病変上外分泌機能障害就よび硬化病変と の関連（表 6)

組織学的病変 16 例中, 外分泌障害は 12 例 $75 \%$, 硬化病 変は15例 $93.8 \%$ と高率に認め，組織学的に病变所見を認 めれば外分泌障害拉よび硬化病変の合併は高率である。 逆に外分泌障害および硬化病変に組稞学的病変を認める 頻度はともに約 $44 \%$ と低率である．しかし，高度の外分 泌障害および硬化病変例では組織学的病変が高率に認め られる。

IV. 随伴性膵障害と臨床像

1）病㮸期間との関連（表 7)

対象72例中, 1 年以上の病悩を有する症例に外分泌障 害がわずかに多くみられた。病悩期間は 1 年末满が39例 $(54.2 \%), 1$ 年以上が33例 (45.8\%) で，外分泌障害の

表 6 組織学的䐙病変と外分泌機能障害および硬化病変との関連

\begin{tabular}{|c|c|c|c|c|c|c|c|c|c|c|c|c|c|}
\hline \multirow[b]{3}{*}{ 組 } & \multirow[b]{3}{*}{ 織 } & \multirow[b]{3}{*}{ 所 見 } & & \multicolumn{5}{|c|}{ 萍外分泌機能 } & \multicolumn{2}{|r|}{ 腪 } & \multicolumn{3}{|c|}{ 度 } \\
\hline & & & & \multirow{2}{*}{$\begin{array}{l}\text { 正常 } \\
\text { 45例 }\end{array}$} & \multicolumn{3}{|c|}{ 障 } & 害 & \multirow{2}{*}{$\begin{array}{c}\text { 正常硬 } \\
\text { 38例 }\end{array}$} & \multicolumn{4}{|c|}{ 硬 化 病 変 } \\
\hline & & & & & $\begin{array}{l}\text { 軽度 } \\
19 \text { 例 }\end{array}$ & $\begin{array}{c}\text { 中等度 } \\
6 \text { 例 }\end{array}$ & $\begin{array}{l}\text { 高度 } \\
2 \text { 例 }\end{array}$ & $\begin{array}{c}\text { 計 } \\
27 \text { 例 }\end{array}$ & & $\begin{array}{c}\text { 軽度硬 } \\
\text { 26例 }\end{array}$ & $\begin{array}{c}\text { 高度硬 } \\
8 \text { 例 }\end{array}$ & $\begin{array}{c}\text { 計 } \\
34 \text { 例 }\end{array}$ & \\
\hline 正 & & 常 & 56 例 & 41 & 13 & 2 & 0 & $\begin{array}{c}15 \\
(26.8)\end{array}$ & 37 & 17 & 2 & $\begin{array}{c}19 \\
(33.9)\end{array}$ & \\
\hline \multirow{3}{*}{$\begin{array}{l}\text { 組織学的 } \\
\text { 膵病変 }\end{array}$} & \multicolumn{2}{|c|}{$\begin{array}{l}\text { 慢性腪炎以外の } \\
\text { 組織学的変化群 }\end{array}$} & 12例 & 3 & 5 & 3 & 1 & $\begin{array}{c}9 \\
(75)\end{array}$ & 1 & 7 & 4 & $\begin{array}{c}11 \\
(91.7)\end{array}$ & \\
\hline & \multicolumn{2}{|c|}{ 慢性获炎 } & 4 例 & 1 & $(11.1)$ & $\begin{array}{c}1 \\
(16.7)\end{array}$ & $\begin{array}{c}1 \\
(50)\end{array}$ & $\begin{array}{c}3 \\
(75)\end{array}$ & & $\begin{array}{c}2 \\
(7.7)\end{array}$ & $\stackrel{2}{(25)}$ & $\begin{array}{c}4 \\
(100) \\
\end{array}$ & \\
\hline & \multicolumn{2}{|c|}{ 計 } & 16例 & $\begin{array}{c}4 \\
(8.9)\end{array}$ & $\begin{array}{c}6 \\
(31.6)\end{array}$ & $\begin{array}{c}4 \\
(66.7)\end{array}$ & $\begin{array}{c}2 \\
(100)\end{array}$ & 12 & $\begin{array}{c}1 \\
(2.6)\end{array}$ & $\begin{array}{c}9 \\
(34.6)\end{array}$ & $\begin{array}{c}6 \\
(75)\end{array}$ & $\begin{array}{c}15 \\
(44.1)\end{array}$ & 15 \\
\hline
\end{tabular}

表 7 病脳期間および背部疼痛と膵障害

\begin{tabular}{|c|c|c|c|c|c|c|c|c|c|}
\hline \multirow{4}{*}{ 病悩期間 } & \multirow{4}{*}{$\begin{array}{l}1 \text { 年 } \\
5 \text { 年 }\end{array}$} & \multirow{2}{*}{\multicolumn{2}{|c|}{$\begin{array}{c}\text { 対 } \\
\frac{72 \text { 例 }}{39} \\
\end{array}$}} & \multirow{2}{*}{\multicolumn{2}{|c|}{$\begin{array}{c}\text { 外分泌障害 } \\
27 \text { 例 } \\
10 \\
(25.6)\end{array}$}} & \multirow{2}{*}{\multicolumn{2}{|c|}{$\begin{array}{c}\begin{array}{c}\text { 硬 化 病 変 } \\
34 \text { 例 }\end{array} \\
17 \\
(43.6)\end{array}$}} & \multirow{2}{*}{\multicolumn{2}{|c|}{ 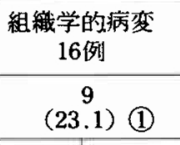 }} \\
\hline & & & & & & & & & \\
\hline & & 22 & \multirow{2}{*}{33} & 11 & \multirow{2}{*}{$\begin{array}{c}17 \\
(51.5)\end{array}$} & 12 & \multirow{2}{*}{$\begin{array}{c}17 \\
(51.5)\end{array}$} & 5 (3) & 7 \\
\hline & & 11 & & 6 & & 5 & & 2 & (3) \\
\hline \multirow{2}{*}{ 背部疼痛 } & なし & \multicolumn{2}{|c|}{44} & \multicolumn{2}{|c|}{$\begin{array}{c}14 \\
(31.8)\end{array}$} & \multicolumn{2}{|c|}{$\begin{array}{c}23 \\
(52.3)\end{array}$} & \multicolumn{2}{|c|}{$\begin{array}{c}10 \\
(22.3)\end{array}$} \\
\hline & あり & \multicolumn{2}{|c|}{28} & \multicolumn{2}{|c|}{$\begin{array}{c}13 \\
(46.4)\end{array}$} & \multicolumn{2}{|c|}{$\begin{array}{c}11 \\
(39.3)\end{array}$} & \multicolumn{2}{|c|}{$\begin{array}{c}6 \\
(21.4)\end{array}$} \\
\hline
\end{tabular}


頻度は 1 年未満で $25.6 \%$ に対し，1 年以上症例で51.5\% と多くみられた. 硬化病変柾よび組織学的病変例と病悩 期間との関湩は頻度差がなく，一定の傾向はみられなか った。なお，組織学的慢性膵炎 4 例中 3 例は 1 年以上の 病悩を有した。

2) 背部疼痛との関連（表 7)

対象症例中, 背部疼痛を訴えた症例は28例38.9\%であ ったが, 表 7 のごとく，䕜障害との関連は全くみられな かった。

3）血液生化学検査成績との関連（表 8)

アミラーゼ值は術前経過中の血清アミラーゼ値 400 IU/1 または尿中アミラーゼ値1600IU/1 (Blue Starch 法) 以上のどららか一方でも認める症例をアミラーゼ上昇例 と判定し検索した.アミラーゼ上杽例は対象72例中11例 (15.3\%)にみられ, 表 8 のごとく, アミラーゼ上昇例 に外分泌障害, 硬化病変, 組織学的病変がともに多くみ られた。

肝機能検査としてビりルビン値, アルカリフォスファ ターゼ值，トランスアミナーゼ值との関連をみたが，ビ
リルビソ值については上昇例が少なく, 統計統計学的対 象とならず，またトランスアミナーゼ值については頻度 差がなく一定の傾向が市れなかった.アルカリフォス ファターゼ值については表 8 に示すごとく，上昇例にわ ずかに硬化病変および組織学的病変例が多くみられが, 外分泌障害例の頻度差はみられなかった。

4) 形態学的検査成績との関連

A. 胆道造影所見との関連

脺病変が胆道におよぽす影響を見る目的で総胆管とく に膵内胆管の形態を検索し, 膵障害との関連を検討し た.

胆道造影所見は排泄性造影 (DIC) または直接性造影 (PTC，ERC) 所見の検索を行い下記項目を検討した.

1. 総胆管の最大径の測定

2. 胆管の走行の検索

3. 胆管の形状の検索

i ) 胆管拡張と脺障害. (表 9)

胆管径の正常範囲は個人差があることより，12mm 以 上を拡張とした．対象72例中 22 例 $30.6 \%$ に胆管抬張がみ

表 8 血清アミラーゼおよびアルカリフォスファターゼ值と膵障害

\begin{tabular}{|c|c|c|c|c|c|c|c|c|c|}
\hline & & \multicolumn{2}{|c|}{ 対 象 } & \multicolumn{2}{|c|}{$\begin{array}{c}\text { 外分泌障害 } \\
27 \text { 例 }\end{array}$} & \multicolumn{2}{|c|}{$\begin{array}{c}\text { 硬化病変 } \\
34 \text { 例 }\end{array}$} & \multicolumn{2}{|c|}{$\begin{array}{c}\text { 組織学的病変 } \\
16 \text { 例 }\end{array}$} \\
\hline \multirow{2}{*}{ アミラーセ } & 正 & \multicolumn{2}{|c|}{61} & \multicolumn{2}{|c|}{$\begin{array}{c}20 \\
(32.8)\end{array}$} & \multicolumn{2}{|c|}{$\begin{array}{c}27 \\
(44.3)\end{array}$} & \multicolumn{2}{|c|}{$\begin{array}{c}12 \\
(19.7)(2)\end{array}$} \\
\hline & 上昇 & \multicolumn{2}{|c|}{11} & \multicolumn{2}{|c|}{$\begin{array}{c}7 \\
(63.6)\end{array}$} & \multicolumn{2}{|c|}{$\begin{array}{c}7 \\
(63.6)\end{array}$} & \multicolumn{2}{|c|}{$\begin{array}{c}4 \\
(36.4)(2)\end{array}$} \\
\hline \multirow{4}{*}{$\begin{array}{l}\text { アルカリフォス } \\
\text { ファターゼ }\end{array}$} & & \multicolumn{2}{|c|}{51} & \multicolumn{2}{|c|}{$\begin{array}{c}19 \\
(37.3)\end{array}$} & \multicolumn{2}{|c|}{$\begin{array}{c}22 \\
(43.1)\end{array}$} & \multicolumn{2}{|c|}{$\begin{array}{c}7 \\
(13.7)(1)\end{array}$} \\
\hline & \multirow{3}{*}{$\begin{array}{r}-10- \\
50- \\
100-\end{array}$} & 16 & \multirow{3}{*}{21} & 5 & \multirow{3}{*}{$\begin{array}{c}8 \\
(38.1)\end{array}$} & 8 & \multirow{3}{*}{$\begin{array}{c}12 \\
(57.1)\end{array}$} & $6(2)$ & \multirow{3}{*}{$\begin{array}{r}9 \\
(42.9) \\
\text { (3) }\end{array}$} \\
\hline & & 4 & & 2 & & 3 & & 2 & \\
\hline & & 1 & & 1 & & 1 & & 1 (1) & \\
\hline
\end{tabular}

表 9 胆道造影による胆管拡張と荤障害

\begin{tabular}{|c|c|c|c|c|c|c|c|c|c|}
\hline \multicolumn{2}{|r|}{ 胆管 $(\mathrm{mm})$} & \multicolumn{2}{|c|}{${ }_{72 \text { 例 }}$ 象 } & \multicolumn{2}{|c|}{$\begin{array}{c}\text { 外分泌障害 } \\
27 \text { 例 }\end{array}$} & \multicolumn{2}{|c|}{$\begin{array}{c}\text { 硬化病変 } \\
34 \text { 例 }\end{array}$} & \multicolumn{2}{|c|}{$\begin{array}{l}\text { 組繊 異 常 } \\
16 \text { 例 (4) }\end{array}$} \\
\hline \multirow{2}{*}{ 非扗張 } & \multirow{6}{*}{$\begin{array}{r}1 \\
-9 \\
9 \\
-12- \\
1 \\
1 \\
-15-1 \\
5 \\
-20- \\
5 \\
-30- \\
5\end{array}$} & 39 & \multirow{2}{*}{$\begin{array}{c}50 \\
(69.4)\end{array}$} & 13 & \multirow{2}{*}{$\begin{array}{c}14 \\
(28)\end{array}$} & 15 & \multirow{2}{*}{$\begin{array}{l}17 \\
(34)\end{array}$} & 5 (1) & \multirow{2}{*}{$\stackrel{5}{(10)}$ (1) } \\
\hline & & 11 & & 1 & & 2 & & 0 & \\
\hline \multirow{4}{*}{ 拡 張 } & & 10 & \multirow{4}{*}{$\begin{array}{c}22 \\
(30.6)\end{array}$} & 6 & \multirow{4}{*}{$\begin{array}{c}13 \\
(59.1)\end{array}$} & 7 & \multirow{4}{*}{$\begin{array}{c}17 \\
(77.3)\end{array}$} & 5 (1) & \multirow{4}{*}{$\begin{array}{c}11 \\
(50)\end{array}$} \\
\hline & & 7 & & 4 & & 6 & & 4 (1) & \\
\hline & & 3 & & 2 & & 3 & & 1 & \\
\hline & & 2 & & 1 & & 1 & & 1 (1) & \\
\hline
\end{tabular}


られ，結石所在部位別には無石 5 例中 2 例 (40\%), 胆 裹結石53例中 8 例 $(15.1 \%)$,胆管結石14例中12例 $(85.7$ \%)にみられた. 外分泌障害の頻度は胆管桩張例で59.1 \%と非拡張例の $28 \%$ に比べ高率で, 硬化病変の頻度も非 抎張例の34\%に対し扗張例で77.3\%と差がみられ, さら に組織学的病変も非拡張例の10\%に対し50\%にみられ, 胆管拡張例には明らかに随伴する脺障害が高率に認めら 机た。

ii ) 胆管の形態と膵障害

胆管の形態を走行と形状に分け，その異常像を図 3 の

図 3 胆道造影による形態分類

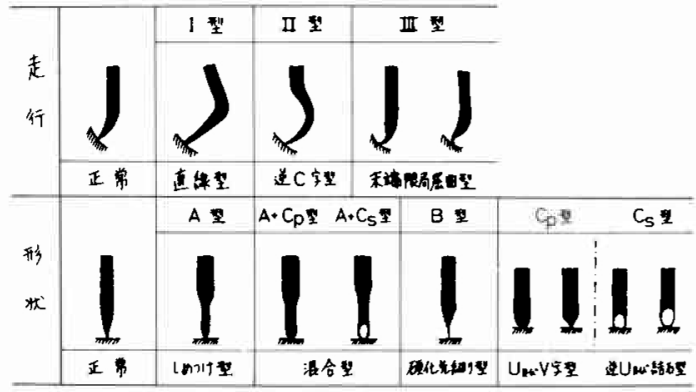

ごとく分類した・すなわら走行異常は，

I 型，直線型（または逆く字型）

II 型 逆 $\mathrm{C}$ 型

而型 末端限局屈曲型

形状異常は
A型 しめつけ型

B型 硬化先細り型

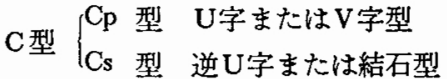

A + C 型 混合型

に分類し検索した。これ等異常像はかなり微細な変化 まで読影し検索対象とした。

a ）胆管走行異常と脺障害（表10）

対象72例中 31 例 $43.1 \%$ に走行異常を認めた. 外分泌障 害の頻度泟正常例の $26.8 \%$ に対し $51.6 \%$ 之高く，乳頭部 近傍病変を反映する III型では頻度差はなく，I＋Ｉ型で は61.9\%と明らかに高率であった，硬化病変も同様に正 常例の34.1\%に対し64.5\%と高率で，とくに I + II 型で は76.2\%と明らかに高く，組織学的病変の頻度も9.8\% に対し $51.6 \% ， I+I I$ 型で $66.7 \%$ と同様に高率であっ た。すなわち，胆道走行異常例では明らかに膵の外分泌 障贵, 硬化病変, 組織学的病変の合併頻度がともに高 く, 乳頭近傍病変を反映する正型では頻度差はみられな いが，膵頭部病変を反映する I，II 型では明らかに随伴 性脺障害が高率であった。

b ) 胆管の形状異常々膆障害（表10）

形状異常を呈した症例は72例中28例38.9\%であった. らち外分泌障害の頻度は正常例の $27.3 \%$ に対し $53.9 \%$ と 高率で，C型では差がみられないが，A，B执よびA+ $\mathrm{C}$ 型では76.9\% と高頻度であり，硬化病変の頻度も同様 に31.8\%に対し71.4\%と高率で，とくにA，B叔よび

表10 胆道造影による胆管の形態と膵障害

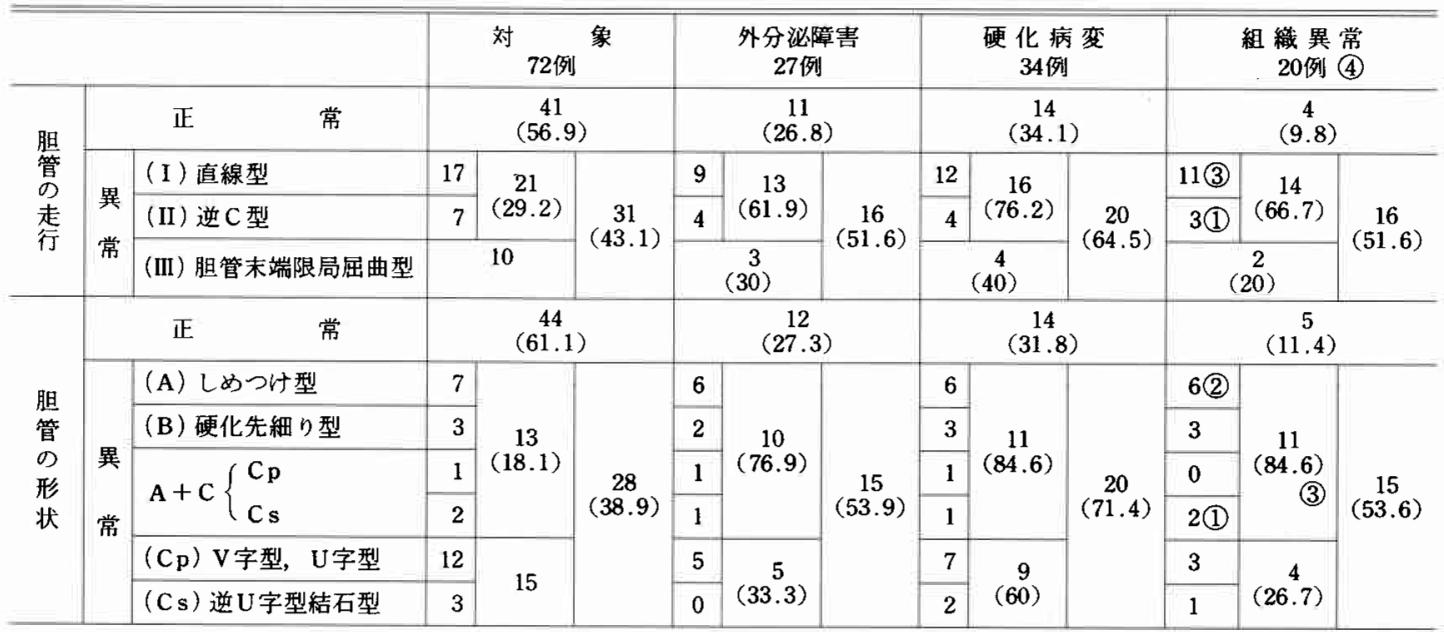


表11 低緊張性十二指腸造影における形態異常

\begin{tabular}{|c|c|c|c|c|c|c|c|c|c|c|c|c|c|c|}
\hline & & & \multicolumn{3}{|c|}{ 対 72 例 } & \multicolumn{3}{|c|}{$\begin{array}{c}\text { 外分泌障害 } \\
27 \text { 例 }\end{array}$} & \multicolumn{3}{|c|}{$\begin{array}{c}\text { 硬化病变 } \\
34 \text { 例 }\end{array}$} & \multicolumn{3}{|c|}{$\begin{array}{l}\text { 組織 異 常 } \\
20 \text { 例 (4) }\end{array}$} \\
\hline \multicolumn{2}{|c|}{ 正 } & 常 & \multicolumn{3}{|c|}{$\begin{array}{c}24 \\
(33.3)\end{array}$} & \multicolumn{3}{|c|}{$\begin{array}{c}4 \\
(16.7)\end{array}$} & \multicolumn{3}{|c|}{$\begin{array}{c}4 \\
(16.7)\end{array}$} & \multicolumn{3}{|c|}{$\begin{array}{c}2 \\
(8.3)\end{array}$} \\
\hline 不 & \multicolumn{2}{|l|}{ 明 } & \multicolumn{3}{|c|}{$\begin{array}{c}4 \\
(5.6)\end{array}$} & \multicolumn{3}{|c|}{$\begin{array}{l}1 \\
(25)\end{array}$} & \multicolumn{3}{|c|}{$\begin{array}{c}2 \\
(50)\end{array}$} & \multicolumn{3}{|c|}{$\left(\begin{array}{l}0 \\
0\end{array}\right)$} \\
\hline \multirow{6}{*}{ 異常像 } & \multirow{3}{*}{$\begin{array}{cc}\text { 䐙 頭 部 } \\
\text { 異 常 群 }\end{array}$} & 圧 排 & 10 & \multirow{3}{*}{$\begin{array}{c}19 \\
(26.4)\end{array}$} & \multirow{6}{*}{$\begin{array}{c}44 \\
(61.1)\end{array}$} & 8 & \multirow{3}{*}{$\begin{array}{c}13 \\
(68.4)\end{array}$} & \multirow{6}{*}{$\begin{array}{c}22 \\
(50)\end{array}$} & 9 & \multirow{3}{*}{$\begin{array}{c}16 \\
(84.2)\end{array}$} & \multirow{6}{*}{$\begin{array}{c}28 \\
(63.6)\end{array}$} & 7 (2) & \multirow{3}{*}{$\begin{array}{c}14 \\
(73.7)\end{array}$} & \multirow{6}{*}{$\begin{array}{c}18 \\
(40.9)\end{array}$} \\
\hline & & 二重陯廓 & 4 & & & 2 & & & 3 & & & 1 & & \\
\hline & & 辺縁不整 & 5 & & & 3 & & & 4 & & & 6(2) & & \\
\hline & \multirow{2}{*}{$\begin{array}{l}\text { 乳頭部近傍 } \\
\text { 異 常 群 }\end{array}$} & 直線状硬化 & 8 & \multirow{2}{*}{$\begin{array}{c}17 \\
(23.6)\end{array}$} & & 3 & \multirow{2}{*}{$\begin{array}{c}5 \\
(29.4)\end{array}$} & & 5 & \multirow{2}{*}{$\left(41^{7} .2\right)$} & & 2 & \multirow{2}{*}{$\begin{array}{c}2 \\
(11.8)\end{array}$} & \\
\hline & & 乳頭部硬化 & 9 & & & 2 & & & 2 & & & 0 & & \\
\hline & 走行異常群 & $\begin{array}{l}\text { 逆 S字, } \\
\text { S䆘走行 }\end{array}$ & \multicolumn{2}{|c|}{$\begin{array}{c}8 \\
(11.1)\end{array}$} & & \multicolumn{2}{|r|}{$\begin{array}{c}4 \\
(50)\end{array}$} & & \multicolumn{2}{|c|}{$\begin{array}{c}5 \\
(62.5)\end{array}$} & & \multicolumn{2}{|c|}{$\stackrel{2}{2}$} & \\
\hline
\end{tabular}

（）\% ○内は慢性脇炎例数

$\mathrm{A}+\mathrm{C}$ 型では84.6\%の高頻度を呈した. 組織学的病変の 頻度も11.4\%に対L53.6\%，とくにA，B打よびA+C 型では84.6\%にみられた。すなわち，胆管形状の異常例 でも同様に, 外分泌障害, 硬化病変, 組織学的病変が之 もに多くみられ，ちち乳頭部病变あるいは胆管未端結石 による形状異常例では正常例とあまり差はみられない が，膵病変を反映するA，BおよびA+C型では明らか に随伴性膵障害が高率にみられた。

B . 低緊張性十二指腸造影 (以下 HDG と略称) 飞㧤 ける形態異常と脺障害 (表11)

四 4 低緊張性十二指腸造影所見の分類

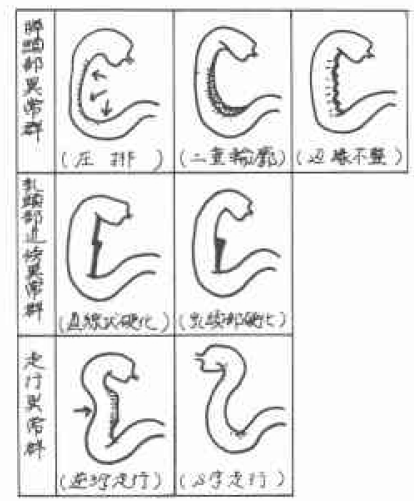

HDG による形態異常はかなり微細な变化も含め図 4 のごとく，脺頭部病変による変化として压排，二重輪 廓, 辺縁不整像, 乳頭部㧍よびその近傍の病变に上る変 化として直線状硬化, 乳頭部硬化, 走行異常として逆 3 字, S 字走行に分類した. これら異常像は対象72例中44 例 $61.1 \%$ Kみれ，亏ち外分泌障害の頻度は正常例の
$16.7 \%$ に対し， $50 \%$, 硬化病変の頻度も正常例の $16.7 \%$ に対し $63.6 \%$ ，組織学的病変子同様に $8.3 \%$ に 対 240.9 \%と明らが HDG 異常例に高率であった. 乙か乙乳頭 部拉よびその近傍の病変を反映する直線状硬化, 乳頭部 硬化像例では正常例上り頻度としては高いが，あまり高 率ではなかった。すなわち, HDG 異常例には随伴性荟 障害の合併頻度が高く, とくに膆頭部病変を反映する二 重輪廓，排圧，辺縁不整像例では著明であった。

\section{考 察}

胆石症之膵病変の関連は, 膵资に合併する胆石症の頻 度が高率であり, 胆石症に対する外科治療が膵炎の再発 を防止できるなどの臨床的事実に基づいている。この胆 脺相関の実態を文献にもとめると，急性膵炎に合併する 胆石症の頻度は欧米では剖検で $41 \sim 54 \%$, 臨床で $48 \sim 78$ \%と非常に高率で, 本邦では欧米程ではないが, 戸田 $23.3 \%$ ，佐藤 ${ }^{3)} 30.4 \%$ ，築山( $36.5 \%$, 村田 ${ }^{5)} 40.5 \%$ の報 告で30\%前後の頻度と推定される.著者教室および関連 施設で経験した急性脺炎53例では19例35.3\%に胆石症の 合併をみている ${ }^{6}$ ．このように急性脺炎には胆石症が高 率に合併することよりその第1の成因とされている。一 方慢性膵炎飞合併する胆石症の頻度は欧米で1.8 50\% と差が大きく，Creutzfeldt \& Schmith" は1778例の集 計で平均 $27.2 \%$, Soergel ${ }^{8}$ る約 $26 \%$ の頻度を推定し ている. 本邦では11.5 24.3\% ${ }^{499101}$ の報告で，1971年 の石井 ${ }^{11)}$ の全国集計 では337例中66例19.5\%とされ，約 $20 \%$ 前後の頻度と推定される。このように慢性膵炎の病 因でも胆石症はアルュールに次ぐ頻度で，合併頻度とし ては決して低率ではなく，急性および慢性膵炎には胆石 症の合併が高く, 両者の相関の事実は疑ら余地もない。 
また，合併する胆石症がその成因とされる事実に関し， Howard ${ }^{12)}$ は急性脺炎鎮静後, 胆石除去を行わなかった 症例の $53 \%$ が $1 \sim 7$ 年以内に再発し, 胆石除去を行った 症例では $5 \%$ 以下に減少したとし，TrapneII ${ }^{13)}$ も同様の 結果を報告して括り，合併する胆石症に対する治療が脺 炎再発に関連する大きな因子となって和り，胆石症が膵 炎の成因とされる由縁ですある。

さて，逆泹石症に合併する脺炎の頻度についてみ ると，急性膵炎の頻度は欧米で $0.54 \sim 1.6 \%$, 本邦でも $0.35 \sim 1.8 \%{ }^{14) 15) 16)}$ で内外をとわず $2 \%$ 以下で，慢性膵 资の合併頻度も同様に低く, 欧米で0.9 3.3\%, 本邦で $3.6 \sim 8.55 \% \%^{14) 15) 17718) 199}$ の報告で，著者の今回の検索で も組織学的に僈性脺炎と診断しえたのは72例中 4 例5.6 \%であった.

このよらに膵炎に合併する胆石症の頻度は高率である のに反し, 逆に胆石症に合併する膵炎の頻度は非常に低 率で両者の関連が疑われるほどである。しかし, 詳細に 検索すると胆石症には機能的あるいは器質的に障害が軽 い軽症脺资々も推測しうる随伴性膵障害がかなり高頻度 に合併している事実がみられる。すなわち，外分泌障害 に関し，Berger ${ }^{20)}$ はオリーブ油刺激にて約 $90 \%$ ，藤山 ${ }^{21}$ も硫酸マグネシウム刺激にて $84 \%$ の障害を認め，PS 試 験による外分泌障害については芳賀 ${ }^{14)} 25.2 \%$, 建部 ${ }^{199} 28$ $\%$, 中野 ${ }^{22} 38 \%$, 鶴 ${ }^{(5)} 55.5 \%$ を報告し, 第 2 回膵研の主 題 “胆石症之膵炎”では約 $25 \sim 60 \%$ 頻度が 発表され $た^{23)}$. 著者む胆石症 72 例中 $37.5 \%$ に認め, 万ち 3 例の慢 性脺炎を除く24例 $33.3 \%$ は外分泌機能面よりみたいわゆ る随伴性脺障害であった。

開腹時の膵所見についても三宅 ${ }^{16}$ は胆道疾患1196例中 手術施行例の $44.7 \%$ に脺の硬化病変を認め, 軽度硬 18.5 $\%$ ，高度硬 $26.2 \%$ を報告している. 香月 ${ }^{24)}$ も $32.7 \%$ 亿， 鶴 ${ }^{15)}$ は60\% 亿認めており, 著者も軽度硬 $36.1 \%$, 高度硬 $11.1 \%$ の $4.2 \%$ に膵の硬化病変を認め, 万ち 4 例の慢性 膵炎を除く $41.6 \%$ は脺の硬化度よりみた膵障害例であっ た.また, 胆石症にみられる脺の組織学的変化にいらて も, 診断基準の相異はあるが, 盛山 ${ }^{25)} は 97 \%$, 白井 ${ }^{26)}$ は $70 \%$ の線維化を認め, 芳賀 ${ }^{14)}$ は慢性膵炎以外の軽度組織 学的病変として151例中23例15.2\%を報告している。著 者も今回の検索で72例中, 慢性脺炎と診断しえたのは 4 例 $5.6 \%$ であるが，炎症性所見を特有とした軽度の組織 学的変化を認めた症例が12例16.6\%で, これらは組織学 的見地よりみられた膵障害である。このように胆石症に は脺炎の診断基準に組しない軽症の随伴性脺障害がかな
りの頻度に合併している。

さて, 胆石症に随伴する膵障害に打ける外分泌機能障 害と硬化病変の関連について, 鶴 ${ }^{15)}$, 香月 ${ }^{24)}$ は膵硬化度 の增加につれ外分泌障害の随伴頻度が高率となり, とく に全体硬群にあっては高度外分泌障害が高頻度にみられ るとL，同様に山形 ${ }^{27)} ら$ 脺の肉眼所見と外分泌機能は 良く相関するといしている，著者の今回の検索でも両者 の相関傾向はみられるものの, 明らかな相関とはいいが たかったすすなわち，外分泌障害例に合併する硬化病変 は74.1\%にみられ，外分泌障害の程度が高度になるにつ 机硬化病変の合併頻度が增し相関傾向は示したが，外分 泌機能正常例にも31.1\%に硬化病変がみられ，内 3 例は 高度硬化例であり，また，逆に硬化病変に合併する外分 泌障害の頻度は $58.8 \%$ とあまり高率とはいいがたく，外 分泌障害より硬化病変の存在はある程度推測しえても, 逆に硬化病変より外分泌障害の存在は推測しがたく, 膵 の硬化よりその機能を推定することは困難に思われる． これは脺の硬化病変の組織学的変化に原因を求めざるを えない，すなわち, 胆石症に随伴する膵の硬化といら変 化が外分泌機能の低下を反映する組織学的变化を示すと はかさらないということで, 鶴 ${ }^{15)}$ は全体硬は, Periductal fibrosis を初めとする線維增加の，またやや硬は軽度の 線維增加之浮腫性病態の反映である可能性が推論できる としている. 著者の検索では硬化病変例中, 組織学的に 病変を認めたのは44\%の半数以下で, その多くはごく軽 度の線維化と炎症所見を特有とした变化で, 明らかな実 質の線維化を認めた慢性膵炎はわずか 4 例 $11.8 \%$ にしか すぎなかった。そして，逆に組織学的病変に合例する硬 化病変の頻度は93.8\%の高率であり，いいかえれば, 胆 石症に随伴する硬化病変の多くは明らかな実質の線維化 を認める症例は少なく，ごく軽度の線維化を伴い，炎症 性変化を主にした組織所見に原因したものと推定され る.

外分泌障害と組織所見に関しても, 組織学的病変に合 併する外分泌障害の頻度は75\%と高率であるが，逆に外 分泌障害例に合併する組織学的病変は半数以下の $44 \%$ に しかすぎず，残る症例では明らかな組織学的変化を認め えない事上り，外分泌障害に起因する他の因子を考虑す る必要がある．その1つに胆石症という胆道病変の存在 下に批子るPS 試験による外分泌機能の 評価判定に問 題があげられる.胆石症存在下に执いては胆汁分泌機構 に障害が生じ，胆汁が持続的に排出されることはしばし ばみられることであるが， Howat ${ }^{28)}$ は，胆汁の持続的 
流出は必然的に十二指腸液の重炭酸塩濃度の低下に結び つくとし，Dreiling 299 む胆襄収縮不良と関連がある点を 指摘し，PS 試験は胆道が正常な場合においてその診断 法として正当な意義があると述べている，芳賀 ${ }^{(4)}$ む胆石 症に括ける重炭酸塩濃度の低下は膵障害に起因するとい らよりむしろ胆道機能の巽常に基づくものと解釈する方 が妥当としている。著者例でもPS 試験に扣ける一因子 低下では重炭酸塩濃度が約 $2 / 3$, 低下因子総数 の約半数 を占めており，胆道機能に起因した因子を考虑する必要 があろう。

外分泌機能, 硬化度, 組織学的所見の関連について総 括すれば，この三者が明らかに相関を示すのは慢性膵炎 にまで進行した高度障害にのみ認められ，それより軽度 の障害例では相関傾向はみられても明らかな相関とはい いがたい。臨床的には開腹前に膆の器質的あるいは組織 学的変化を推定する方法としては外分泌機能検査にたよ るしかなく, 外分泌障害より硬化病变はある程度推測可 能であるが，組織学的变化は汪とんど予想できない，開 腹を行っても膆の硬度よりその機能および組織学的変化 を推論することもあてにならず, 高度の硬化病変であっ ても外分泌機能が正常で, 組織学的にも所見がみられな い例もあり，膆の硬化度より機能扣よび組織学的変化を 推測することはかなり困難といわざるをえない，乙か し, 組織学的には軽度であっても所見がみられれば外分 泌障害括よび硬化病変は高率に存在する.

それではこのような胆石症に随伴する勝障害の本態は いかなるものであろらか。香月 ${ }^{30}$ は大部分の膵障害が組 糡学的所見に乏しく，脺の硬化も頻度が低く，PS 試験 るほとんど軽度異常を示すことより，慢性膵炎とは区別 し, 胆石症に随伴する “胆石膵障害”などと呼称すべき ことを提晿している. Haward ${ }^{12)}$ Trapnell ${ }^{31)}$ らは gall stone pancreatitis の膵の線維化は一定限度にしか進行 せず，臨床的にも良好な経過をとるとし，Mallet-Guy ${ }^{32)}$ らの Kopfpancrcatitis の中には極めて軽度の組織学的变 化も含められて括り，Sales ${ }^{33)}$ らは胆石症に随伴する膵 炎は胆石症手術後には治窑することから，実際には再発 性急性腈炎で慢性膆炎とは区別している．著者も組織学 的検索にてあきらかな線維化を有する慢性症所見に之し いことより，慢性脺炎といらよりむしろ軽症の急性膵炎 の部類に属するものと考学て括り，その組織学的变化は 内藤 ${ }^{34)}$ のい5慢性脺资への進展過程で表される $1 \sim 2$ 期 に相当するすのと推定している.

さて，このような胆石症に随伴した膵障害はどのよう
な経過をとるのであろうか：これら膵障害は臨床症状が 軽度なため, 胆道疾患に隠れ, 組織学的にも多くは可逆 的変化にとどまることより，その原因である胆石症の治 療によりほとんど治癒していくといわれる。しかし，こ の膵障害もその原因が除去されないとその経過中に炎症 の急性増覀あるいは慢性化の過程をとる可能性も充分に 予想され，ここに随伴性脺障害のもつ臨床的意義が存在 する. 鶴 ${ }^{15)}$ は胆石症 117 例中 $55.5 \%$ に脺障害を認め, そ の追跡調查により 3 年経過後も10.3\%の遺残を推定して 打り, 胆石症手術予後に関与する因子として随伴性膵障 害が存在することを示唆している。すなわち, 胆石症に 対する適切な時期を失しない治療は胆石症の治療のみな らず，随伴する脺障害の治療と進展防止となり，ひいて は胆石症の手術成績と予後を良好ならしめる因子として 関与しているのであろう。

慢性膵炎の臨床像は一般に周知されているが, 胆石症 に随伴する脺障害の臨休像についての報告は少ない，衍 前にその存在を知る方法としては PS 試験が唯一の方 法であろうが，症例の全てに施行するわけにむいかず， PS 試験を施行する症例の選択をする必要がある，そこ で著者は術前のごく一般的臨床検查成績より随伴する膆 障害の臨床像の検索を行った。

結石の所在部位別では胆衰結石に比へ，胆管結石群に 䏽障害が多くみられここれは諸家の報告と一致してい る. 胆石症の病悩期間については芳賀 ${ }^{14)}$, 鶴 ${ }^{15)}$ は差を認 めず，著者例では病悩 1 年以上例で外分泌障害がやや多 みみられたが, 硬化病変, 組織学的病変の頻度差はな く，全般的には関連はみられなかった。背部疼痛は膵炎 に一応持有とされるが，胆石症にも比較的よくみられる 症状で，膵障害との関連はみられず，他の一般的自覚症 状でも同様であった，血液生化学検查における肝機能検 査成績ですほとんど有意差は認められなかったが，血清 および尿中アミラーゼ上昇例では随伴する脺障害が多く みられた。

脺病変を間接的にとらえる一般的な形態検查法として 胆道造影と HDG があるが，下部胆管は膵後部を通り， 一部膵内を貫通し, 一方, 十二指腸係蹄は膵を取り团 み，しかもその下行内側には胆管および膵管の開口する Vater 乳頭が存在するなど，解剖学的見地より膵病変が 胆管および十二指腸に反映されることは容易に推測でき る.

著者は胆道造影所見から随伴する膵障害の胆管への影 響を胆管径と脺内胆管の形態变化から検討したが，胆管 
拡張例および胆管の形態異常をみる症例には明らかに腜 障害が多くみら礼た。大藤 ${ }^{35)}$ は胆石症で急性膵炎を合併 した症例の大多数が胆管の拡張を示し, 胆管末端部にお ける病変の存在が認められたとし, 一方芳賀 ${ }^{14)}$ は胆石症 123例の脺の組織学的検索に扎いて, 高度病変群では胆 管抎張例が多いが, 病変がみられない群と軽度病変群で は胆管拡張の有無による頻度差は認めなかったとしてい、 る.著者の検索では明らかに胆管拡張例に随伴性脺障害 の合併が高率であったが，胆管扗張の原因はほとんど結 石によることより，胆管結石例に随伴する膵障害が高率 であると解した方が妥当と考えている。

膵の炎症性病変による胆管の走行異常について, Sachs $^{36)}$ は lateraldisplacemant, angulation, proximal displacement, compression の 4 stage に分類し, 胆管の変 形過程は膵病変の広さと程度に比例するとしといる.著 者の検索では軽微な变化まで読影し, 走行異常像は43.1 \%に認め，これらに随伴性脺障害が多くみられた. Sachs の lateral displacement および Schein ${ }^{37)}$ の reversed C としての直線型および逆C型についてはさらに莘障害の 随伴頻度は高率となり，慢性膵炎の4例はいす゚れもこれ らの走行異常を呈した。胆管末端の限局属曲型は乳頭あ るい㥒頭周辺の限局性病変がらかがわれる所見で, 脺 障害の合併頻度は正常例と頻度差はみられなかった。

従来, 慢性膵炎に和ける胆管の形状異常として, しめつ け像が典型とされ, 態谷 ${ }^{38)}$ は硬化直線型, 硬化先細り型, 逆 $\mathrm{C}$ 走行型, 限局狭少型の 4 型に分類し, これら胆管像 が慢性膵炎に特徽的で，診断率は false negative $13 \%$, false positive $28.6 \%$ とし, 大藤 ${ }^{35}$ も慢性膵炎の胆道像 を走行と形状の異常に分類し，膵炎診断にお汁る有用 性をとき，去の病因論的考察も行い，胆石合併膵炎には 硬化先細り型および指頭状，漏斗状の胆管像が特徵的 で, 萃炎発生に和ける胆管末端部の病変が膵炎発生上重 要であることを示唆している. 今回の著者の検索では胆 管の形状異常が38.9\%にみられ，これら症例には脺障害 例が有意に多くみられた。しかし, 乳頭部病変, 䏣管末 端部結石を反映するU字および結石型などの胆管像では 硬化病変をのぞき他は正常例の頻度と大差なかった。そ してとくに, 膵病変を反映するしめつけ型, 硬化先細り 型，扣よび混合型では明らかに随伴性膵障害の合併が高 率にみられた。慢性膵咨における明らかな胆管形態異常 像の合併頻度は大藤 $86 \%$, 熊谷 $87 \%$ と高率であるが，胆 石症例でも詳細な読影を行らと, 慢性膆炎程明らかな変 化としてとらえられなくても，それに類似した軽微な異
常所見として認められ，これらには合併する随伴性脺障 害存在の可能性が推測でさる.脺障害の頻度が高率に認 められる胆管像として, 走行異常より直線型と逆 C型, 形状異常よりしめつけ型, 硬化先細り型执よび混合型を ともに認める形態異常例は10例13.9\%で，これに合併す る外分泌障害, 硬化病変, 組織学的病変は泣とんど全例 に認められ, この内, 慢性脺炎の 4 例を除く, 6 例は明 らかに随伴性脺障害による胆管の形態変化と解され, 慢 性膵炎ほどの高度病変がみられない膵障害例でも, かな り高率に胆管の形態的異常をみることがでさる。

HDG は Jacquemet ${ }^{39)}$ により創案され，以来，胆道

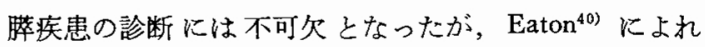
ば，本法による慢性膵炎の所見発見率は64\%と述べてい る. 中沢 ${ }^{411}$ は本法に括ける十二指腸下行内側脚の側面像 を $\mathrm{A}$ および $\mathrm{E}$ 型の基本分類し, 膵病変と組織学的にも機 能的にも相関がみられ，D型および $\mathrm{E}$ 型では尿アミラー ゼ値異常または外分泌障害が高率にみられるとしてい る. 著者は今回の検索で HDG 所見をかなり軽微な変 化まで読み, その異常像として, 膵頭部病変を反映する 像, 乳頭部及びその近傍病変を反映する像, および異常 走行像に大別し，61.1\%に所見を得た. 結石の所在部位 別には㫜䧶結不群で54.7\%に対し, 胆管結石群では78.6 \%と高率にみられ，これら異常像例には明らかに随伴す る脺障害が高頻度にみられ, 特に脺頭部病変を反映する 圧排, 二重輪廓, 辺縁不整像の 3 型では高率の合併がみ られた. 走行異常例でも正常例に比べ脺障害の頻度は高 く，とくに逆 3 字走行は Frostberg ${ }^{42)}$ によれば, 急珄拉 よび慢性膵炎や胆道疾患に多くみられ, 十二指晹内側壁 と脺の癒着により生じるとされ, その周辺の炎症性病変 を示唆するものと推測される.一万, 乳頭部执よびその 近傍病変を反映する乳頭部硬化扣よび直線状硬化像は中 沢の分類のD执よ゙ $\mathrm{E}$ 型を一部含むもので, 乳頭炎や胆 管末端炎あるいは乳頭周辺の限局性膵病変を反映するも のと推定されるが，これら異常像に合併する膵障害の頻 度はあまり高くなく, 黒田 ${ }^{43)}$ は著明な圧迫像や陰影欠 損, 辺縁不整などを呈した例は全て中等度以上の機能低 下および慢性膵资を示すのに対し, 壁硬化像等では膵機 能や組織像との一定の相関は認められなかったとして いる. Ferrucci44) は HDG に护る乳頭部の正常像を Promontory, Straightsegment, longitudinal fold に分け, Promontory は臨床で60\%, 剖検で66\%に, Promontory と Straightsegment の共存は臨床で $25 \%$, 剖検で66\%に みられ，この所見は慢性膵炎時の所見と鑑別が必要と 
し, 黒田も壁硬化像は慢性脺炎に特徽的ではあるが，こ の場合, Promontry の鋭角化を伴うすのとしている.

胆石症にみられる HDG の異常所見は詳細に検討す ると高頻度で, これに合併する随伴性膵障害の頻度は高 く, 特に軽度变化であっても圧排, 二重輪遊, 辺縁不整 の 3 所見では脺障害の随伴する可能が充分推測される.

\section{結 論}

1）胆石症72例中, 䐐外分泌機能障害 27 例 $37.5 \%$, 膵 硬化病变 34 例 $47.2 \%$, 組織学的膵病变 16 例 $22.2 \%$ が随伴 し，これら脺障害は胆襄結石群に比べ胆管結石群に多く みられた。

2）外分泌障害と硬化病変の間には相関傾向がみられ たが，明らかな相関はいずれも高度障害例にしかみられ なかった。

3）組織学的寴病変例飞は明らかに外分泌障害および 硬化病变が高率にみられたが, 逆に外分泌障害および硬 化病変に合併する組織学的病変の頻度は低率であった。 しかし, 高度障害例には組織学的病変が 高率に 合併し た。

4）組織学的慢性膵炎の合併は 4 例 $5.6 \%$ であった.

5）随伴性粹障害々病悩期間, 背部疼痛, 肝機能検查 成績の間には明らかな関連はみられなかった。しかし， アミラーゼ上昇例では愺障害の頻度が高く認められた。

6）形態学的検查所見々脺障害の間には関連がみられ た.すなわち, 胆道造影における胆管扗張例, 胆管形態 異常例には随伴する膵障害の合併が高く, 低緊張性十二 指腸造影飞括ける異常所見例にる, 同様で, 形態学的検 查所見の詳細な読影により膵障害の随伴する可能性がか なり推測し光た。

稿を終るにあたり，ご指導ご校閱いただいた古賀道弘 教授に深甚の謝意を表する。また本研究に際し直接ご指 導いたたいた中山和道助教授に心から御礼申し上げる.

(本論文の要旨は第 8 回日本消化器外科学会総会に拧 いて発表した.)

\section{文 献}

1) Opie, E.L.: Relation of cholelithiasis to disease of the pancreas and fat necrosis. Am. J. Med. Sci., 121: 27-43, 1901.

2)戸田安士, 他 : 急性膵炎の治療. 最新医学, 27: $1688-1695,1972$.

3）佐藤寿雄, 他 : 急性膵炎経過後の病態につい て. 最新医学, $27: 1677-1687,1972$.

4) 筑山義雄 : 膵疾患の躁床. 医学書院, 東京, 1970.
5) 村田 勇, 他 : 急性膵炎, 総合臨床, 18: 2811一 $2821,1969$.

6) 小林重矩, 中山和道, 松永 章: 急性膵炎症例 の検討. 手術, 29: 929-937, 1975.

7) Creutzfeldt, W. and Schmith, H.: Aetiology and pathogenesis of pancreatitis. Scand. .J. Gastroeuterol., 5: 47-62, 1970.

8) Soergel, K.H.: The pancreas. 166-189, Mosby Co., Saintlouis, 1973.

9）槙 哲夫，他：現代外科学大采 (39)，79-91, 中山書店, 東京, 1968.

10) 藤本 稔: 膵蔵病. $211-234$, 医学書院, 東京, 1970.

11) 石井兼央, 他：慢性膵炎の病因, 最新医学, 27: 1704-1710, 1972.

12) Howard, J. and Jordan, G.L.: Surgiacal diseases of the pancreas, 170-206, J.B. Lippincott Co., Philadelphia, 1960.

13) Trapnell, J.E.: The natural history and prognosis of acute pancreatitis. Ann. Roy. Coll. Surg. Eng., 38: 265-287, 1966.

14）芳賀紀夫 : 胆石症と膵障害との関連についての 病理組織学的研究. 日消病会誌，70：820一 $833,1973$.

15）鶴敬雄：胆石症に随伴する慢性蕠障害の臨床 的観察。日消病会誌, 70：792-810，1973.

16) 三宅 博：胆石症，金原，東京, 1970 .

17）秋田八年：胆道疾患の展望一とくに関連疾患を 中心として一綜合臨床, $18: 2769-2778,1969$.

18）斉藤洋一，佐藤寿雄：胆石症と脺障害一特に慢 性膵炎との関連から一日消病会誌, $70: 1103$, 1973.

19) 建部高明, 他：慢性膵炎一特に膵外分泌機能 上 りみた訩断基準一日本臨床，31：103-108， 1973.

20) Berger, H.A. and Tennant, R.A.: Statistical study of acute hemorrhagic pancreatitis. Am. J. Med. Sci., 196: 167-173, 1936.

21) 藤山省吾 : 胆石症患者八膵機能二就テ：岡山医 会誌, $53: 2262-2279,1941$.

22) 中野 哲: 橧瞒病钐断学, 膵外分泌機能検査, 126 182, 医薬出版社, 1974 .

23）第 2 回 日本䐙臓病研究会秋期大会シーディグ, 1：2号, 日本愺搭病研究会編, 1971 .

24）香月武人：手術中触钐による膵硬化がもたらし たもの, 臨床と研究, 50:1704-1711，1973.

25) 盛山真行, 他 : 䏣石症と愺障害. 第 2 回日本膵 炡病研究会秋期大会プロシーディグ, $1: 2$ 号, 32-33, 1971.

26) 白井智行, 他: 胆石症と膵障害, 第 2 回日本膵 蔵病研究会秋期大会プロシーデイング, 1:2 号, 34-35, 1971.

27) 山形䑤一, 他：慢性膵炎, 胃と腸, 2 : 649$655,1967$. 
28) Howat, H.T.: The biliary system. Blackwell, Oxford, 1965.

29) Dreiling, D.A.: The technique of the secretin test normal ranges. J. Mount. Sinai. Hosp., 21: 363-375, 1955.

30) 香月武人：胆石症と膵障害. 日消病会誌, 70 : 1054--1061, 1973.

31) Trapnell, J.E.: The pathogenesis of gallstone pancreatitis. Postgrad Med. J., 44: 497-597, 1968.

32) Mallet-Guy, P. and Beaujeu, M.J.: Treatment of chronic pancreatitis by unilateral splanchicectomy. Arch Surg., 60: 233-251, 1950.

33) Sales, H., et al.: Observations on 205 confirmed cases of acute pancreatitis, recurring pancreatitis and chronic pancreatitis. Gut., 6: 545-559, 1965.

34) 内藤聖二, 他 : 慢性膵炎の臨床. 臨床外科, 23: $1141-1151,1968$.

35) 大藤正雄, 熊谷哲夫: 経皮的胆道造影.最新医 学, $27: 1747-1756,1972$.

36) Sachs, M.O. and Partington, P.F.: Cholangiographic diagnosis of pancreatitis. Am. J. Roentgnol., 76: 32-38, 1956.

37) Schein, C.J.: The common bile duct, opera- tive cholangiography, biliary endscopy and choledocholithotomy. Charles C. thomas, Springfteld, 1966.

38) 熊谷哲夫：膵炎と胆道病变，特に胆管末端病变 との関係について一胆道X線像による考察を主 として一。 日消病会誌, 68:84-101， 1971.

39) Jacquemet, et al.: The early diàgnosis of disease of the pancreas and ampulla of vater. 21-48, Charles C Thomas, Springfield, Illinois, 1965.

40) Eaton, S.B., et al.: Hypotonic duodenography. Radiologie Clinics of North America, 8: 125137, 1970.

41) 中沢三郎：低緊張性十二指腸造影. 最新医学, $27: 1742-1746,1972$.

42) Frostberg, N.: A characteristic duodenal deformity in cases of different kinds of perivaterian enlargement of pancreas. Acta Radiol., 19: $164-173,1938$.

43）黑田 慧, 他 : 十二指腸X線一低㗨張性十二指 胆造影を中心に一。治療, 58：1542- 1548, 1976.

44) Ferrucci, J.T., et al.: Radiographic features of the normal hypotonic duodenogram. Radiology, 96: 401-408, 1970. 